Orbis Tertius, vol. XXIV, $\mathrm{n}^{\circ}$ 30, e142, noviembre 2019-abril 2020. ISSN 1851-7811

Universidad Nacional de La Plata

Facultad de Humanidades y Ciencias de la Educación

Centro de Estudios deeoría y Crítica Literaria

\title{
Roland Barthes, Vita Nova. Santiago de Chile, Marginalia, 2018, 72 páginas
}

Publicar un libro de ocho páginas es un gesto curioso. Publicar un libro de ocho páginas de Roland Barthes desde una joven editorial chilena es escribir un nuevo episodio de la historia del persistente barthesismo latinoamericano. Pero publicar, además, Vita Nova - el último proyecto del autor y del que llegó a escribir tan solo estas ocho páginas- es tensar el nudo de lo póstumo, es ir al corazón de esa condición. Tal como señala Éric Marty, "la obra póstuma es aquello que vuelve más próximas la obra, la literatura y el espacio de la muerte, en una proximidad tan perturbadora que su publicación provoca a veces polémica”. Aquí no es tanto polémica cuanto sorpresa lo que genera el texto por su condición mínima y frágil.

Publicar este libro de ocho páginas es, en suma, completar el libro que Vita Nova podría haber llegado a ser. Pero completarlo no con un Prólogo (aunque éste lo lleva, luminoso, a cargo de David Fiel), no con notas (aunque éste las lleva, intervenciones del traductor Ernesto Feuerhake); es completarlo con esa diferencia que luego de recorrer la distancia que va de la palabra arcaica (un proyecto) a la palabra definitiva (la obra "terminada") es el salto que un texto cualquiera hace hacia esa unidad completa, a la que nada le falta ni le sobra: un libro. Es ir un paso más allá del camino que separa el querer-escribir del poder-escribir y hacer de una pieza de archivo un libro.

En el mismo sentido en que Vita Nova junta un comienzo de obra (las notas de un proyecto) y un final de obra (un libro), junta también un comienzo vital (la vida nueva tras "la decisión del 15 de abril de 1978 ") y un final (el accidente, la muerte de Barthes). Es decir, un umbral (el medio del camino) se vuelve de pronto un límite para la vida y esa sombra es lo primero que el lector de Vita Nova tiene presente cuando se dispone a leer esas notas. Pero la muerte, en realidad, lo recorre todo en este auténtico último Barthes, pues todo comienza, como en Dante, con la muerte (en este caso, de la madre) y todo lo que escribe lo hace en estado de duelo. La vida nueva es, por lo tanto, la vida que una muerte hace posible. Quizás por ello en el octavo y último folio de Vita Nova el duelo es el comienzo o, anota Barthes, el final del libro futuro.

La vida nueva es simplemente una idea: "entrar en novela". Así la define Barthes. Abandonar la vida mundana y comenzar la vida en novela. Como Proust. No se trata, sin embargo, de un problema de géneros. Barthes hace de la novela una imagen cuya función es trazar un límite exterior de la propia obra, como en Borges, como en Rodolfo Walsh. Y también un límite exterior del yo: "llamo Novela no a un género sino a toda obra donde hay trascendencia del egotismo, no hacia la arrogancia de la generalidad sino hacia la simpatía con el otro". En suma: Vita Nova no es una novela, pero no sólo por su brevedad ni por su carácter inconcluso. Es otro movimiento barthesiano que al sacudirse logra intensificar la quietud. Por ello sería un error pensar que en lugar de escribir una novela habla sobre ella, que en Vita Nova la novela es un tema y no una práctica, del mismo modo que sería un error pensar la novela como superación de la escritura, como su espacio de consumación. Por ello Vita Nova incluye, como decisión, el abandono del relato de la propia vida nueva.

Lo que este libro pone en juego es una fuerza que produce movimiento. Quizás todo se reduzca, en este Barthes, al movimiento. Es lo que anuncia en Preparación de la novela: "Debo salir de este estado tenebroso, adonde me conduce el desgaste de los trabajos repetidos y el duelo. Este encasillamiento, este hundimiento inmóvil en arenas movedizas (¡que no se mueven!)”. De allí surge la resolución: cambiar. Pero para un escritor, 
cambiar es encontrar "una nueva práctica de escritura". Es decir, en Barthes cambiar es el mejor modo de no cambiar. Encontrar una nueva práctica de escritura es simplemente poder seguir escribiendo. La vida nueva no es el corte abrupto, el gesto heroico, la irrupción de la Voluntad. No. Es simplemente seguir escribiendo. Se trata de un movimiento teórico que quizás pueda comprenderse a través de un concepto que Barthes usa en Lección inaugural, la excentricidad. Barthes se apoya en "las fuerzas excéntricas de la modernidad" para desplazarse a través de un sedentarismo intensivo. Así se puede leer, quizás, el cuadro en que Barthes divide su obra en $R B$ por $R B$, precisamente como eso: lo que cuenta es la coherencia, la persistencia, la testarudez con la que el autor se dispone a buscar una única cosa de todos los modos posibles. Esa única cosa recibe muchos nombres - lo neutro es quizás el definitivo (y el de mayor vigencia en el presente).

Ahora bien, Vita Nova es, al mismo tiempo, un libro críptico (es sólo un índice) y claro, pues todo suena ya a los libros que Barthes había publicado. ¿Qué se lee entonces, si no se trata de una novela, en Vita Nova? Se lee el tiempo del pensamiento que busca una forma. Así el proyecto varía y cambia de lógica y de personajes. También se lee una inflexión de un aspecto importante de este Barthes: una moral y una política. Y se lee una depuración que incluye el abandono de la posibilidad de narrar. Por eso en estas 8 páginas la unidad de escritura es la palabra y lo que Barthes pone en juego es la resonancia de determinadas palabras, palabras a esa altura "barthesianas". Pero en ese proceso se pone en juego mucho más: su obra completa, es decir, lo "ya hecho". En suma, aquí están presentes, al mismo tiempo, la obra nueva (sólo alcanzable a partir de una vida nueva) y el peso de la vida vieja, la obra, el pasado, el recuerdo, los muertos.

Quizás lo fundamental de Vita Nova como texto vacío es que es una manera de volver sobre la obra que lo soporta (la obra completa de Barthes) y recorrerla con otro índice (el propio libro Vita Nova), para encontrar allí lo que conocemos y otras cosas (incluso la novela). Pero Vita Nova no esconde una verdad (como casi ninguna pieza de archivo): por el contrario, hace ver que ya conocíamos todo, que todas esas palabras ya estaban en nosotros como un saber arcaico. Barthes tomó algunas para hacer con su obra ese gesto que ya había hecho: cambiar para ser fiel a su deseo de persistir. La obra y la vida nueva ingresan así en otro terreno, el de lo posible. Es lo que se lee en el final del libro: "El Círculo de mi posible = la Literatura. Decisión del 15 de abril del 78: La literatura". ¿Qué otra cosa que "la literatura" había sido su "posible” y su "decisión"? Un posible y una decisión que esta Vita Nova descubre como una vía de acceso a la calma. Incluso al Bien y a la felicidad.

En La preparación de la novela, Barthes narra el episodio que da lugar a "la decisión del 15 de abril del 78", al nacimiento de Vita Nova:

Y ahora un poco de anécdota personal: ¿cuándo fue tomada esta decisión de "cambio"? El 15 de abril de 1978. Casablanca. Pesadez de la tarde. El cielo se nubla, refresca. Vamos en grupo, en dos autos, a la Cascada (hermoso Valle de la ruta de Rabat). Tristeza, cierto tedio, lo mismo, ininterrumpido (desde un duelo reciente) y que se refleja en todo lo que hago, lo que pienso. Regreso, departamento vacío; ese momento difícil, la tarde. Solo, triste. Reflexiono con bastante intensidad. Eclosión de una idea: algo así como la conversión "literaria", son esas dos palabras antiguas las que vienen a mi mente: entrar en literatura, en escritura; escribir como si no lo hubiera hecho jamás: hacer solamente eso. Ante todo, idea brusca de abandonar el Collège para unificar una vida de escritura. Luego, idea de investir el Curso y el Trabajo en la misma empresa (literaria), en beneficio de un único Proyecto, el Gran Proyecto, imagen de dicha. El 15 de abril, en suma, especie de Satori, de deslumbramiento, análogo a la iluminación que el Narrador proustiano experimenta al final del Tiempo Recobrado (pero ¡su libro ya está escrito!).

Lo que probablemente Barthes descubrió al comenzar a escribir Vita Nova es que el suyo también ya estaba escrito. 